\title{
Business History and the Organization of Industry
}

\author{
Jackie Krafft
}

\author{
AFFILIATION: \\ CNRS Researcher at CNRS-IDEFI
}

\section{ADDRESS:}

CNRS-IDEFI, 250 rue Albert Einstein, 06560 Valbonne, France, Tel: 33-4 939541 70; Fax: 33-4 936537 98; E-mail: jkrafft@idefi.cnrs.fr

\begin{abstract}
:
This paper focuses on recent developments of business history on a specific theme : the boundaries of firms and industries. Connexions with industrial organisation, and especially with neo-institutionalism, have increasingly appeared in the literature. Connexions are generally developed according to two main tendencies which are discussed in the paper. We show that the first tendency uses economic models dealing with information problems as a benchmark for the analysis of historical facts, while the second tendency offers the opportunity to refine some of the principles of industrial organisation by taking into account the emphasis of business history on a concrete problem of innovative firms and industries : the coordination of productive activities.
\end{abstract}

\section{KEY WORDS :}

Business history, industrial organization, neo-institutionalism, coordination of information, coordination of productive activities, innovation and competences

JEL Classification : A 12, L 10, L 20, N 80. 


\section{Introduction}

Business history emerged in the 1950s as a sub-discipline of economic history, and its initial domain of investigation was the characterization of the evolution of entrepreneurs and firms at the individual level. Progressively, business history became a discipline in itself, enlarging the scope of analysis, and developing closer connections with the broad economic field of industrial organization. With this transformation, business history - now often called "new business history" - can be defined as the analysis of the evolution of the structures and behaviours of firms and industries over long periods of time, within a framework which explicitly takes into account markets and institutions that shape these structures and behaviours. Today, research programmes mixing business history with the theory of the firm and industrial dynamics are burgeoning ${ }^{1}$. The major goal of these common research programmes is to characterize the robustness of key results obtained in industrial organization on specific periods analyzed by business historians, and to generate new propositions especially on the question of what determines the boundaries of the firm or the boundaries of the industry.

This paper analyses whether this emerging interdisciplinary connection may or may not contribute to what we already know as economists in the domain of the theory of the firm and industrial dynamics. In this analysis, we think that two conditions can be considered as crucial. First, the appreciation of the value of research into business history should permit one to observe at the same time general results in theory of the firm and regularities in industrial dynamics that are not determined contextually, but also critical differences and anomalies that, throughout history, make certain firms or industrial patterns of evolution unique. Second, the confirmation of some general conclusions obtained in theory of the firm or industrial dynamics should not obscure or leave apart some important results extracted from business history. With these conditions in mind, the paper stresses that, in practice, there are two different trends under which connections between business history and industrial organization were conducted in various interdisciplinary research programmes. The first tendency is to use the data collected by business historians to answer key questions that structure the theory of the firm and industrial dynamics. Here, a selection of economic models on the firm and the

\footnotetext{
${ }^{1}$ See for instance "Development of the American Economy" at NBER, "History Friendly Modelling" at Bocconi and "Innovative Enterprise and Historical Transformation" at INSEAD.
} 
industry is operated in order to provide a consistent interpretation of empirical data over the long run. The second tendency proceeds the other way around, since it consists in the questioning of economic results on the firm and the industry by referring to puzzles and questions emerging from business history archives. Here, long run historical data is generally used as a way to increase the variety of economic models able to understand these questions and puzzles, rather than to select them a priori. The two trends reveal diverging methods to deal with the relation between theoretical and empirical work.

The paper shows that the first tendency essentially concerns major neo-institutionalist theories of industrial organization, namely transaction costs approaches, agency theories, and property rights analyses. In the connection with business history, these theories privilege problems of coordination of information to understand the firm and the industry, but neglect in the meantime other major determinants of their structure and evolution. Alternatively, the second tendency tends to characterize problems related to the coordination of economic activities that are so central in innovative firms and industries, and often necessitate elaborating new theoretical perspectives on neo-institutionalism, especially by fostering approaches focusing on innovation and competences.

The argument will be grounded on the valuable contributions made by Alfred Chandler on the connections between business history, the theory of the firm and industrial dynamics. In fact, this pioneering work can be exploited according to two alternative interpretations that have structured the literature so far. In this perspective, we show in a first step that the tendency centred on the information coordination is in the line of a Williamsonian interpretation of Chandler, and ends up with a confirmation of existing results in the theory of the firm and industrial dynamics by business history (Section 2). In a second step, we show that the tendency centred on the productive coordination restores the essential ideas of Chandler on the connection between business history and industrial organization, and ends up with a real confrontation of results between the two disciplines (Section 3). In a third step, we derive some new perspectives on business history and the organization of the industry, specifically by focusing on firms composing the automobile sector (Section 4). 


\section{When business history confirms industrial organization: a focus on the coordination of information}

Since the 1980's, neo-institutionalist approaches to the theory of the firm and industrial dynamics offer a basic framework to elaborate connections between business history and industrial organization. Transaction costs approaches, firstly, have contributed to analyse the emergence and viability of large, vertically integrated firms in the United States in the beginning of the $20^{\text {th }}$ century. Secondly, agency theory has provided an in-depth analysis of the relationships between shareholders and managers, and potential conflicts between stakeholders. Finally, property rights analysis has significantly refined the analysis on the boundaries of the firm. Despite these advances, key challenges still remain. In fact, the outcome of these different contributions is essentially to show that business history confirms industrial organization on the key problem of the coordination of information.

\subsection{Coordination of information in the context of opportunism and asset specificity}

One of the preliminary connections between business history and industrial organisation started with the interpretation of Alfred Chandler by Oliver Williamson in the domain of the theory of the firm. The main object of Chandler in his book Visible Hand published in 1977 is to understand major characteristics of the industrial revolution which started at the end of the $19^{\text {th }}$ century in the US and subsequently shaped the modern industrial system. Chandler focuses on the reasons why the US economy is so largely dominated by large companies for a major part of the $20^{\text {th }}$ century. Starting from monographs of significant companies, the projected outcome is to draw major characteristics of long term viability companies over large panels of population. Chandler then generates two essential characteristics. The first characteristic is that companies which engaged massively capital intensive activities were generally confronted to a major problem of coordination. This problem was to articulate a mass production with a mass distribution. The second characteristic is that the problem of coordination of capital intensive activities could generally not be resolved automatically, relying on the sole market forces. Within these capital intensive industries, vertical integration (backward or forward) could permit firms to avoid bottlenecks on the supply side and to 
generate new demand opportunities by the coordination of different yet complementary productive units. The argument is that managerial coordination superseded market coordination in industries characterized by high economies of speed, i.e. in which production is sufficiently high and rapid to decrease unit costs. Investment in organizational capacity to manage vertically-related units emerged as a key of competitive success. As a matter of fact, companies which did not invest in organizational capacity exited, while companies which invested became the leaders of the industry.

Oliver Williamson, in Chapter 5 of his book The Economic Institutions of Capitalism published in 1985, uses the different cases of vertical integration examined by Chandler as empirical evidence of his own theory based on transaction costs. Williamson argues that firms involve the minimization of transaction costs in specific situations. Firms emerge when investments are characterized by a high degree of asset specificities, since the sunk costs character of these investments generally involve some hold up behaviours from managers, leading to the expropriation of their rents. In this theoretical framework, the proposition is that the higher (respectively the lower) the transaction costs, the higher the chances to allocate resources within a firm (respectively within a market). In this framework, vertical integration represents a 'paradigmatic problem' (Williamson, 1985, p. 150) for the theory of the firm based on transaction costs. Williamson acknowledges that the empirical verifications of his own theory on the basis of the monographs done by Chandler are to some extent preliminary and rudimentary. However, the major outcome is that, in most cases, business history on vertical integration supports the theoretical proposition based on transaction cost, and discards alternative theoretical proposition. In conclusion he stresses that a predictive theory of vertical integration should essentially refer to asset specificity and opportunism.

Three comments result from this connection between business history and the theory of the firm. The first comment is that Williamson derives from this connection the dominant explanation of why the US economy was characterized in the early $20^{\text {th }}$ century by large, vertically integrated companies. Vertical integration appears as the optimal governance structure (minimizing transaction costs) since opportunism linked up with asset specificity is eliminated. The second comment is that Williamson argues from this connection that transaction costs theory of the firm is superior to any other theories of the firm developed so far. Former theories of the firm can essentially identify technical determinants explaining basic mechanisms of integration (mundane integration), but sophisticated forms of vertical 
integration (exotic integration) are explained by transaction costs approach to the theory of the firm. The reason is that in addition to production costs integrated within traditional theories of the firm, Williamson focuses on the minimization of the sum between production and transaction costs. The third comment concerns economies of speed. This notion leads to erroneous conclusions for Williamson, since it leads to justify vertical integration in industries in which there is no asset specificity. This notion introduced by Chandler does not differ from technical complementarity argument advanced in traditional analysis of the theory of the firm, and as such is not able to capture the large diversity of integration forms.

A lot of further contributions were developed in this line of reasonning, following the argument provided by Williamson (Wiggins, 1991; Shelanski and Klein, 1995; Ménard, 2000). The measure of transaction costs, or at least their operational characterization in an empirical context, was considered as a major problem in the initial steps. Today, the usual method lies in the decomposition of transaction costs into their different core elements (asset specificity, uncertainty, frequency of transactions), and to characterize the impact of each element on the optimal mode of governance. Even if this method does not correspond to the original Williamsonian frame in which the different elements are intrinsically related, it certainly produced a huge amount of new results. As a matter of fact, transaction costs theory has now an operational content which favours empirical developments, including closer connections with business history. A number of contributions were also centred on the generalisation of the multidivisional form within Companies in the US, in Europe and Asia (Hannah, 1983; Kocka, 1971; Morikawa, 1975; Reader, 1975; Wilson, 1968; Grieves, 1989). Business history here is in the line of one of the key theme developed by Chandler, i.e. the definition of an internal structure able to collect and diffuse information, and the basic theoretical references lies in a combination between transaction costs approaches and agency theory.

\subsection{Coordination of information in the context of asymmetric information and diverging incentives}

Asymmetric information and diverging incentives are at the core of agency theory (Tirole, 1988). This theory focuses on how institutions can be efficiently structured and run when information is not equally distributed among the actors. Raff and Temin (1991) analyse the possible links between this theory and the internal organization of firms within business 
history. The firm is the usual domain of application, since owners-managers relationships, managers conflicts, and manager-employee interactions are analysed, but extends also to industrial dynamics on the question of how the boundaries of an industry are modified over time.

Very often, managers and owners have diverging interests, and owners have a limited capacity in observing what managers really do. Agency theory argue that in this context, owners can be incited to invest in monitoring mechanisms to improve their knowledge on the private information of managers, or impose remuneration schemes to motivate managers to act in the owners' interest. In this situation, the main problem is thus to define monitoring and compensation systems to reach efficiency. Business history shows that these questions are not pure theoretical questions, since they were largely observed in many cases throughout history. In addition, mechanisms implemented in practice were not significantly different from the recommendations of agency theory. De Long (1991) shows that monitoring systems implemented by top managers at the bank JP Morgan have significantly improved the performance of client companies. Lamoreaux (1991) focuses on how these information problems have influenced the loan strategy within US banks. Finally, and within a more recent historical period, many of the agency theory recommendations were implemented within firms in order to increase the efficiency of corporate government (Holsmstrom and Kaplan, 2001; Tirole, 2001; Schleifer and Vishny, 1997; Jenkinson and Mayer, 1982). Asymmetric information alters the contractual terms under which investors are willing to invest, as well as the structure and strategy of firms in terms of mergers and acquisition, cessions and downsizing. Asymmetric information has also important consequences on the evolution of the population of firms, since the need of funds varies a lot with the business cycle (Calomiris and Hubbard, 1995).

Agency theory also includes managers conflicts, and refer also to monitoring and compensation schemes. Carlson (1995) uses these arguments to analyse the case of the Thompson Houston Electric company which was significantly affected by such conflicts of interests. Even if managers had the same collective goal, namely the success of the company, their ranking within the company and their position within different and unconnected services, drove to sub optimal strategies. Johnson (1991) also shows that erroneous interpretation or wrong utilisation of financial accounting by senior managers led to great inefficiencies in production. 
On manager - employee relationships, Davis (1996) reviews different incentive mechanisms which were implemented by top managers in US companies at the beginning of the $20^{\text {th }}$ century to stimulate employees. Most of these incentives mechanisms are related to the development of a certain kind of appropriation of the company by the employees. Korczinski (1999) explains that the emergence of trade unions in the UK over the period 1960-1980 can be seen as contributing to the limitation of opportunistic behaviours from the employees.

Finally, asymmetric information and diverging interests can also have an impact beyond the sphere of the firm, involving major industrial restructurings. British colonies used to rely on specific agencies, the Crown agents, to convey luxury goods between UK and its colonies over the period 1880-1914 (Sunderland, 1999). When British colonies have realised that Crown agents could manipulate information on the quality of goods, a monitoring system was put in place involving that British colonies and UK could simply trade directly, without any intermediary agent. The outcome of this restructuring was thus the disappearing of specific intermediary actor which was considered fundamental in the former industrial configuration.

\subsection{The coordination of information in the context of property right}

Grossman and Hart (1986) and Hart (1995) have defined property as the power to exercise control. For these authors, the theory of the firm is not based on different structures of remuneration for employees and contractual agents, and thus cannot be reduced to agency theory propositions. For these authors too, the boundaries of the firm should not be determined exclusively by the greater advantage to limit opportunism, as in transaction costs theory. In fact, the theory of the firm is here defined in reference to the entity which has the residual rights of control, i.e. the entity which controls the decision variables in the last resort. Contributions in business history have tried to back up this theory with empirical data, though archive material appears to be less numerous and affirmative. Lamoreaux (1998) and (2001) shows that even if this theory is often presented as one of the most appealing and challenging, some important difficulties emerge as soon as empirical verification is implemented. On the basis of organizational choices developed by entrepreneurs in the $19^{\text {th }}$ century, Lamoreaux shows that the tradeoff between integration and partnership cannot be clearly proved on the pure basis of the property rights arguments. 


\subsection{Business history and industrial organization on the coordination of information: summing up}

Major neo-institutionalist approaches to industrial organization, namely transaction costs, agency theory and property rights generally play an important role in business history contributions since they offer a simple, suitable framework. Compared to neo-classiscal theories of the firm, neo-institutionalist approaches certainly render the connection between the two disciplines simply possible, since they focus on the same object of study: the firm as a complex system of interactions, the boundaries of which may evolve over time. In this perspective, business history contributions have shown that institutional forms are modified over time and that these modifications can be explained by problems of coordination of information, such as private information and opportunism. Imperfection or asymmetry of information in the redaction and enforcement of contracts, the appropriation of rents, the behaviours of contracting parties, justify in most cases the transformation of market coordination into managerial coordination supporting an integrated structure. Information problems can also be at the origins of entry and exit phenomena shaping the boundaries of the industry.

This connection between business history, the theory of the firm and industrial dynamics, seems to be affected however by three major limits. The first concerns the reference to the "comparative analysis of institutions" (Williamson, 1989, p. 136) which assumes possible the definition and the comparison of respective efficiencies of different forms of institutions. With this notion, nothing can be said on the conditions of emergence and viability of institutional or industrial forms. The second limit is connected to the deductive method which is often used in the connection between economic analysis and business history. The third limit is related to the systematic reduction of complex phenomena involving the coordination of industrial activities to simpler issues such as the imperfection or the asymmetry of information.

\section{1) Comparative analysis of institutions}

This notion explicitly involves that one can compare different forms of institutions in order to define the optimal structure using the criteria of the minimization of transaction costs. This notion was extensively used in transaction costs analyses, but also in other dominant neo- 
institutionalist approaches such as agency theory and property rights. In all of these theories, costs and advantages of alternative forms of institutions (firms, market, cooperation) are evaluated, and this evaluation exhibits an efficient solution solving information and incentive problems. This procedure is not significantly different from intertemporal optimization and even mechanical convergence towards equilibrium, all neo-classical notions that have always been so vividly rejected by major authors in business history ${ }^{2}$. The major problem is that the question of the evolution of institutional forms and the progressive predominance of one mode over the other is reduced to the instantaneous calculus of the optimal solution. Temporality, in which actors interact concretely and coordinate progressively, is completely neglected, while it is so central to business history.

\section{2) Deductive method and confirmation}

The relation between theories and facts is always critical ${ }^{3}$. The predominance of a deductive method naturally leads economists to consider real-world phenomena as potential illustrations of their theoretical frame. The sequence of reasoning can be summarized in the following way: theoretical hypotheses are defined $\Rightarrow$ the optimal organizational structure for the firm/industry is determined $=>$ empirical applications are defined. But beyond this theme, the question of how interdisciplinarity operates is also concerned. The value of interdisciplinarity is present when each discipline jointly brings in new elements that were not apparent when disciplines were working in isolation. In the present case, industrial organization brings in theoretical frames, while business history provides data. This division of labour between disciplines is never changed or questioned in the sense of the opportunity for business history to generate also new theoretical propositions, i.e. propositions that were not already included within industrial organization frames and results. Confirmation of theory by facts is thus the priority, and not a confrontation between different theories coming either from industrial organization or business history.

\section{3) Focus on the coordination of information}

The focus on information problems is not a problem in itself. Most of the advances provided in industrial organisation since the 1970s are centred on this question. A difficulty emerges, however, when this focus becomes exclusive in that it obscures other questions, such as the coordination of productive activities (Richardson, 1960, 1972; Loasby, 1991). This difficulty

\footnotetext{
${ }^{2}$ See, for instance, Supple (1961); Hyde (1962); Wilson (1997); Lee (1990a and b); Jones (1997).

${ }^{3}$ See Fisher (1991), but also Kaldor (1985) and Hayek (1937).
} 
is present in business history. For Chandler, the essential determinants of the predominance of vertical integration lie in the coordination of productive activities, and especially in the articulation between mass production and mass distribution. Williamson transforms this former interpretation into a problem of coordination of information. When Williamson interprets Chandler, vertical integration is justified by the existence of opportunistic behaviours in capital intensive industries where assets are highly specific. The argument of Chandler is significantly modified, and the status of empirical verification advocated by Williamson is closer to a confirmation of his own theory than a real confrontation between industrial organization and business history.

\section{When business history confronts industrial organization: questions and puzzles on the coordination of productive activities}

In this paragraph, we show that in some cases, problems related to the coordination of productive activities are at the centre stage of business history studies. The main argument is based on the real problematic of Chandler which is not centred on the coordination of information, but the coordination of productive activities in innovative firms. Lazonick first restored the main content of this problematic, and Chandler himself in more recent contributions stressed that the interpretation which is provided by neo-institutionalist approaches to the firm is not adapted to his monographs of innovative firms. The coordination of productive activities requires the development of alternative visions of the firm, such as the ones developed in terms of dynamic capabilities. We suggest thus new interpretations of business history studies on the basis dynamic capabilities theories of the firm and industry.

\subsection{The coordination of productive activities: the Chandlerian innovative firm}

In his book Business Organization and the Myth of the Economy published in 1991, Lazonick criticizes the interpretation provided by Williamson on the work of Chandler. For Lazonick, the Williamson-Chandler relationship is not a pure connection between theory (based on 
transaction costs) and facts (based on business history). Rather, this relation should be considered as the confrontation between two distinct theories on the specific issue of vertical integration. In this perspective, it appears that Williamson essentially proposes a theory of adaptive firms, i.e. a theory in which the behaviour of firms is constrained by the structure of the environment. On the other hand, Chandler advances in the field of innovative firms on the basis of a theory in which the behaviours of firms shape the structure of the environment ${ }^{4}$.

The argument is the following. First, the economies of speed characterized by Chandler cannot be assimilated to pure technical problems as described in Williamson's book. Second, the emergence of vertical integration analysed by Chandler cannot be assimilated to the reaction against opportunistic behaviours which is so central to Williamson. The four essential cases examined by Chandler (Duke, Kodak, Swift, and Singer) were concerned by the emergence of a technological innovation, but the essential thing in each of these cases was that new forms of organizations were to be elaborated in order to coordinate a mass production with a mass consumption. Vertical integration dominated because it was one of the possible solutions to this specific problem of coordination of productive activities. In fact, well before the technological innovation came out on the market, networks of production and distributions were in development. The implementation of a capital intensive programme generally involved for the company to maintain a regular flow of input for the effective utilisation of productive capacity, as well as a sufficient flow of output structuring the establishment of a market which formerly was inexistent. When these conditions were not observed, the weight of sunk costs generally highly questioned the viability of the innovative firm.

For Lazonick (1991, p. 198-199), the essential problem lied in the transformation of high fixed costs into low unit costs. Chandler (1992) confirms that the economies of speed generally implied to strengthen the capacity of production as well as the intensity of utilisation of this capacity. In the meantime, this increased fixed and sunk costs, and this required to be counterbalanced by low unit costs in final production. The engagement of a triple investment, i.e. the elaboration of distribution networks, the elaboration of networks in commercialization and marketing, and the definition of a specific organization dedicated to coordinate the different phases of the process of production, was crucial to the coordination of

\footnotetext{
${ }^{4}$ Se also Lazonick $(2002,2003)$.
} 
mass production and mass market. This triple investment was the source of durable competitive advantages. In labour intensive industries, however, such triple investment was not observed, essentially because in that case investments were neither fixed nor irreversible. With this interpretation, the explanation of the dominance of vertical integration goes largely beyond the problem of opportunism linked with asset specificity ${ }^{5}$.

\subsection{The coordination of productive activities: the role of competences in the process of innovation}

In 1992, Chandler provides a contribution in which he clarifies his position on industrial dynamics and the theory of the firm. To him, the firm is necessarily at the centre stage and its essential functions, i.e. first production, and second exchange, require an in-depth investigation. Neo-classical visions of the firm, but also agency and even transaction costs theories, are of any help solving this problem (Chandler, 1992, 85-86) ${ }^{6}$. Within neo-classical approaches the firm is considered as a technical unit dedicated to maximize a specific function, on the basis of a closed set of information. This clearly does not correspond to the concrete production problems that a firm has to face throughout business history. Within agency theory and transaction costs theory, the basic unit of analysis is not the firm but rather the transaction or any contractual arrangement. In fact, the empirical phenomenon he has collected and analysed are much more in coherence with an analysis in terms of evolution of competences. More specifically, Chandler advances that the alternative theory of the firm which is more in accordance with his work on business history is certainly the analysis in terms of dynamic competences the origins of which are in Marshall, Schumpeter, Penrose and the more recent developments in Teece, Dosi, Lazonick and Nelson (ibid., p. 86). As a matter of fact, Chandler criticizes thus some of the utilization of his own work, and especially the interpretation by Williamson which was however considered as one of the key mode of connection between business history and the theory of the firm. Another important teaching is

\footnotetext{
${ }^{5}$ Again, according to Lazonick (1991, p. 242-243), “In referring to Chandler's material on Swift, Williamson demonstrated his unwillingness (or inability) to comprehend the Chandlerian emphasis on high throughput and economies of speed. Paraphrasing Chandler on the reasons for Swift's ultimate success, Williamson argued that "despite the opposition from the railroads and butchers, Swift's 'high quality and low prices' combined with 'careful scheduling' prevailed". Compare this statement with the quote from Chandler that I have just reproduced and emphasized. For Williamson, it was not worth mentioning the other factors - "high volume and the speed... of product flow" - that Chandler included in the same phrase as "careful scheduling" (the factor that Williamson did quote) as ways in which Swift attained the "high quality at low prices" that enabled him to win the market". ${ }^{6}$ See also Chandler et al. $(1997,1998,2000)$.
} 
that the emerging collaboration between business history and the theory of dynamic competences.

\subsection{Production and organization of industry: towards an operational framework}

Langlois and Foss (1999) stress that the specificity of the analysis in terms of dynamic competences is to give the opportunity to generate a rebirth of a problematic centred on production in a theory of industrial organization dominated so far by an exclusive focus on transaction problems. Referring to Richardson (1960, 1972) who explicitly relates the 'capabilities' that characterize the productive knowledge of firms with the 'activities' that compose the production process, Langlois and Robertson (1995) propose a theory of industrial dynamics. Activities can be similar, i.e. based on the same set of competences; and activities can also be complementary, i.e. related within a process of production ${ }^{7}$. The confrontation of different degrees of similarity with different degrees of complementarity can generate a matrix guiding the choice between different forms of organization of industry. The essential question is to know whether new competences can be acquired externally via the market, inside the firm, or on the basis of interfirm cooperation. The answer depends on a first type of element which concerns the structure of competences and the location of the different bits that compose this structure of competences, i.e. inside the firm, via cooperation or via the market. The second type of element depends on the nature of innovation, i.e. whether innovation is systemic and requires a simultaneous change of all the different parts of the production process, or whether innovation is autonomous and requires the simultaneous change of some of the different parts of the production process (see also Teece, 1986).

\begin{tabular}{|l|l|l|}
\hline Structure of competences & Systemic innovation & Autonomous innovation \\
\hline Inexistent & Vertical integration & Vertical desintegration \\
\hline Existent & Vertical desintegration & Vertical desintegration \\
\hline
\end{tabular}

Table 1: Competence, innovation, and the vertical structure of the industry

In Chandler' cases, some of the companies (Swift and Kodak) decided to engage a vertical integration strategy very early. In other cases (Duke and Singer), companies first experienced

\footnotetext{
${ }^{7}$ For Richardson, the process of production regroups the activities of conception, production, commercialization and distribution. This vision thus corresponds to an extended definition of the process of production.
} 
vertical disintegration, leaving distribution networks to operate independently. In a second step, they opted for vertical integration by the internalization of these distribution networks. Swift and Kodak were confronted to a systemic innovation coupled with the inexistence of the structure of competences. The innovation in Swift was systemic since the essential activity of this firm (i.e., production and transport of congealed meet) required the modification of all the different parts of the traditional production and distribution processes. The productive challenge was to elaborate specialized and refrigerated containers that could be transported by railways from one city to the other. The market challenge was to attract a sufficient customer base for this new product. In fact the former structure of competences was not adapted to these new challenges, since no one before Swift decided to engage in such an innovation project. For Kodak, innovation was systemic too. The productive challenge was to generate a new process in the development of photography, replacing the old system on frames by a new one using rolls incorporated within the camera. The market challenge was to attract non professional photographers to us a simple, integrated product. In this case, also, the structure of competences was inexistent, since Kodak was the first developer of this technology and no other companies could either compete on a similar activity or contribute in a complementary manner to the new photography process. Vertical integration was here the sole organizational mode able to create the new competences involved in the innovation process and transform them into market opportunities. For Duke and Singer, the existence of a network of independent retailers with adequate competences naturally led these companies to disintegrate.

\subsection{Business history and industrial organization on the coordination of production: summing up}

Though less recognized compared to transaction costs theory, agency theory and property rights theory, the approach in terms of dynamic competences provides a framework on industrial organization able to redefine connections with business history. This approach centred on innovation and the creation, development, and accumulation of competences restores the vision of the link between business history and industrial organization that was contained in the initial contributions of Chandler. This link is characterized by 3 new elements. 


\section{1) Diversity and evolution of institutions}

Business history and industrial organization, within this vision, have to focus on the way in which the activities undertaken are divided up among firms, namely why and how some firms embrace many different activities while for others the range is narrowly circumscribed, why and how some firms are large and others small, why and how some firms are vertically related and others not. Business history and industrial organization have to describe and analyse how the firm and the industry are organized now, but also how they differ from what it was in earlier periods. The connection between these two disciplines have to contribute to understand what are the forces that were operative in bringing about a given organization at the level of the firm or the industry, and how these forces have changed over time. The two disciplines have to jointly characterize the coherence that exists within a specific firm or industry - for instance what determines the boundaries of the firm and the industry, who does what and why within the firm and the industry, and what forces are crucial to their functioning - as well as the diversity that may exist among different firms or different industries.

\section{2) Inductive method and confrontation}

Business history and industrial organization have to capture some regularities in observed phenomena and elaborate on this basis some plausible and testable assumptions to understand these regularities. In this perspective, business history and industrial organization have to privilege an analysis of the process by which a given trend of evolution has been achieved, and why some diverging path may also be obtained. The sequence of reasoning is here: observed organizational structures are determined $\Rightarrow$ regularities and anomalies are characterized and confronted to theoretical results $=>$ new theoretical propositions are generated. This inductive method restores a real confrontation between the two disciplines by considering that each of them can equally contribute to the observation and analysis of a phenomenon. Both disciplines can equally provide data and theoretical assumptions that, together, may generate a better understanding of this specific phenomenon.

\section{3) Focus on the coordination of production}

The coordination of productive activities is an essential problem in innovation, but too often neglected. The reintroduction of this key element in the connection between business history and industrial organization is thus an important step in the understanding of innovative firms and industries. However, one should be aware that the exclusive focus on this type of coordination may also generate similar drawbacks as the exclusive focus on the coordination 
of information. In a sense, the connection between business history and industrial organization should develop on the basis of a new mode of confrontation: not only the traditional confrontation between theories and facts, but also between different theories, some oriented towards the coordination of information, some oriented towards the coordination of production.

\section{Business history and the organization of the automobile industry: new perspectives}

In the following paragraph, we proceed with the idea of a confrontation between theories to sustain the link between business history and industrial organization. We focus on a specific industry, the automobile industry, one of the most innovative in the $20^{\text {th }}$ century. On the key questions of the boundaries of the firm and of the industry, we provide new perspectives on the characterization of major determinants, by confronting two distinct theoretical perspectives: one in terms of the coordination of information, the other in terms of the coordination of production

\subsection{Innovation and the evolution of the boundaries of the firm}

Agency theory explains the boundaries of the firm by the differences in remuneration schemes between the manager and the employees. Differences may be attributable to risk behaviours, the manager being supposed to be risk neutral while the employees generally adverse risk Differences can also be linked to private information that the employees have and that the managers attempts to make reveal. Is this vision of the firm applicable to large trends in the evolution of remuneration schemes throughout history?

Some studies in business history explored this question, especially by focusing on the US car industry during the period $1910-1930^{8}$. The major outcome of the studies is that there are two

\footnotetext{
${ }^{8}$ See statistics and censuses on firms' payments schemes provided by the US Department of Labour, Bureau of Labour and Statistics, as well as the National Industrial Conference Board (Raff, 1995; Langlois and Roberston, 1995).
} 
essential factors that contradict the interpretation provided by agency theory. First, remuneration schemes are directly affected by the way in which the different tasks are coordinated, which ultimately depends on the organization of production. This factor is in favour of the predominance of productive information over transaction information in the explanation of the evolution of the boundaries of the firm and remuneration schemes of employees. Moreover, different modes of production were implemented within firms during this period of time, involving different forms in the coordination of tasks, and this may explain the large diversity in remuneration schemes. The second factor is that innovative firms in the car industry, like Ford, have adopted a mass production and a remuneration structure per day in 1913 or 1914. These innovative firms have co-existed with more passive companies that kept their former structure of competences and as well as more traditional remuneration schemes. The generalisation of mass production and remuneration per day was only effective in 1920 .

In fact, at the origins of the car industry, the process of production is highly decomposable. Automobile is a luxury good and car companies are more assemblers than producers. Within each enterprise, a small group of persons have to proceed on the different parts of the car and reassemble them in a process very similar to what was formerly implemented in car horses manufacturing. Each assembler is quite independent from the other, and the rhythm of each single worker is unconstrained by the work done by another worker. In this system, the essential requirement is to produce the largest number of parts, and workers with a high productivity are selected and paid. In this system also, owners of the company have no rights on the manufacturing equipment used in car production, since employees come to the workshop with their own tools. For these reasons, it is quite difficult to distinguish an employee and an independent worker, and the boundaries of the firm are quite fuzzy. The mode of payment is directly dependent on the mode of production: quantity is the priority, and workers are paid in reference to the pieces they provide.

The industry further develops and faces two key changes which were initially introduced by Ford. The first important change is the implementation of the progressive assembly, a system by which the work continues even when the company generates stocks. Tasks of each individual employee become more inter-connected, and it is now necessary to coordinate the rhythm of work of the team. The second important change is the American-system production of parts, which involves the production of standardized intermediary and final goods. 
Investments in manufacturing equipment are now made by the company. With these changes, the assembly line is the place where all the inputs and activities have to be narrowly coordinated. When excess in production appear as a result of a wrong coordination, this may generate important losses for the company. The boundaries of the firm emerge in this new situation: the firm is a set of activities closely linked both technically and economically, implemented by a population of workers and coordinated by a group of managers. Here, the mode of payment is not determined on the basis of individual/team productivity, but in reference to the global productivity of the enterprise. The achievement of the process of production involves the engagement of all the workers and the remuneration is identical for each worker.

The automobile industry was certainly characterized by a systemic innovation. All the tasks and the way in which they were coordinated were redefined at this period. However, systemic innovation was gradually and differently adopted by companies of the industry. Some of the companies even rejected all sort of change and continued to produce in the same manner as they have always done, relying on the former traditional structure of competences of their quasi-independent workers, and keeping fuzzy boundaries. Other firms, most of them becoming soon leaders of the industry (Ford, General Motors, Chrysler), have elaborated a new structure of competences adapted to the development of the systemic innovation, and have created a sophisticated organizational structure. The diversity of these different firms, their characteristics in terms of productive choices, have also had great implications on entry and exit phenomena, and this on the definition of the boundaries of the industry.

\subsection{Innovation and the evolution of the boundaries of the industry}

In the domain of industrial dynamics, one key framework is the Industry Life Cycle or ILC (Gort and Klepper, 1982; Klepper, 1997, 2002a, 2002b). The basic hypothesis is that innovative industries behave like biological organisms, and their characteristics evolve and change depending on the different stages of their lifetime. One of the major results of this body of literature is that market structure, i.e. the number of firms, is highly connected to the stages of diffusion of the innovation within the industry. Here again, business history studies show that this result can be discussed, especially when information problems are privileged to explain this phenomenon in a context of innovation. 
The car industry is one of the specific domain of application of ILC models (Klepper and Simons, 1997, 2000). Empirical work in this industry has generally brought new propositions into the conceptual framework and, in turn, theoretical models were tested in this sector. Using the database from the Federal Trade Commission on the period 1899-1960, for instance, we know the following facts. Growth rate of output is highly increasing up to 1919 (25.8\% per year), and stagnates till 1929 (11.5\% per year). In the period 1930-1937, growth rate decreases, and further slightly rises at the end of the period. The ILC model is here valid, since the growth of output is high during the initial phases of the cycle, and then declines over time. The entry-exit process also evolves according to ILC recommendations. Entry is highly concentrated during the development phase of the industry since, during the period 1902-1910, it reaches on average 48 new firms per year, with a peak of 84 companies in 1907. After 1910, entry rate falls: it reaches 16 new entrants per year in the period 1911-1921, and almost equals zero thereafter. In 1909, exits are superior to entry and thus a shakeout ${ }^{9}$ occurs. Shakeout becomes more important during the 1920s and is maximal in the 1930s. Market shares largely fluctuate initially and stabilize over time, as soon as the leader firms start to gain a dominant market position. In fact, in 1937, three firms Ford, General Motors and Chrysler cover $88 \%$ of the market. These firms will keep their leadership until the 1960s. First movers survive and occupy leader positions in the long run. Entry is common, and there are five major cohorts of entrants (1895-1904, 1905-1909, 1910-1916, 1917-1922, 1923-1967). Entrants coming from these different waves have a similar survival rate during the first seven years, but after the seventh year, former entrants issued from the first wave clearly survive better than later entrants coming from the other four cohorts. A substitution product innovation-process innovation is also observed. Product innovation is maximal in 1905, and concern major innovations on the definition of the basic structure of automobiles. Product innovation further declines and is progressively replaced by process innovation which continues to progress until the mid 1930s.

Business history studies here offer an alternative vision of the phenomenon of shakeout observed during the great depression. Aggregate economic data show that the shakeout confirms the basic teachings of $\mathrm{ILC}$, while business history data seems to suggest that this not

\footnotetext{
${ }^{9}$ Klepper and Miller (1995) define the shakeout in the following terms : the industry is not in a situation of shakeout when the number of firms does not decline below $70 \%$ of the peack or when, going down this threshold, the number of companies rises again at least at $90 \%$ of the peak. With this definition, only 27 out 46 studied initially by Gort and Klepper (1982) face a shakeout.
} 
necessarily the case ${ }^{10}$. ILC advocates that the industry was prospering and that there has been suddenly a huge glimpse with the Great Depression. Business historians show on the contrary that the pattern of evolution was somewhat more complex ${ }^{11}$. Between the two peaks of 1929 and 1933, the total number of incumbent firms is nearly half the initial total, and entry stagnates at $10 \%$ : there is clearly a shakeout. However a complete vision of what occurred involves a deeper investigation into what the firms looked like, what were the characteristics of those who survived between 1929 and 1933, who exited the industry, or emerged as new entrants in the same period.

Firms which disappeared were essentially different from the other two classes of companies. In 1929, when the great depression struck, automobiles were developed according to two different technologies. On the one hand, three major leaders (General Motors, Ford and Chrysler) were precursors in the development of mass production and modern manufacturing methods. On the other hand, other firms were using older technologies, more labour-intensive. The exit process is traditionally analysed by ILC in terms of the access to information and its impact on cost curves. This explanation is not appropriate here. The great depression cannot be considered as a period of transition in which less efficient firms disappeared. Rather it is a key period in which there has been a profound mutation in the industry. Differences in cost curves are thus not central in the argument, since costs curves generally reflect production costs at a specific moment in time. The major element here to understand the massive exit process is in fact the sunk costs that some firms decided to engage, while others firms conserved a more flexible position. When the leaders, capital intensive companies, were faced to low levels of demand, they could not generate high revenues, but more importantly they could not exit the industry voluntarily. Labour-intensive companies on the contrary could exit the industry without major losses. The rationale for the shakeout is thus the engagement in a systemic innovation involving high sunk costs and an internal reorganization dedicated to create new competences, adapted to new productive challenges.

One could finally advocate that the choice of flexible labour-intensive companies, was at the end of the day, purely rational compared to the one of other firms which engaged high sunk costs and faced large losses during the great depression. However, this vision is also very

\footnotetext{
${ }^{10}$ Data in this case are coming from census of producers in 1929, 1931, 1933 and 1935. For this specific industry, and others, these Censuses manuscripts survived in original or microfilm form with essentially complete coverage. The data is therefore suitable for panelization and analysis using sophisticated statistical methods.

${ }^{11}$ Cf Raff (1998), Bresnahan and Raff (1991, 1998).
} 
partial. The leaders, by their irreversible choice, have developed the conditions of their own development and viability. With the sunk costs that the investment in new production methods and new organizational structures, these companies were in position to face mass demand that emerged thereafter. These firms developed productive activities that corresponded to the market configuration, and controlled the articulation between the productive sphere and the market sphere. Other firms failed, they disappeared with the great depression and could never enter again.

\section{Conclusion}

This paper was intended to review the literature on the possible link between business history and the organization of the industry. From the review, we show that a dominant trend considers economic models as a grid to structure historical facts, while an alternative vision leaves business history studies a larger space to refine basic economic frames on the organization of the industry. The paper also shows that in a context of innovation, the dominant trend is often inappropriate to deal with the question of the boundaries of firms and industries. This motivates the development of the second alternative to progress on the understanding of the theory of the firm and industrial dynamics. 


\section{References}

BRESNAHAN, T., and RAFF, D. (1991), "Intra-industry heterogeneity and the great depression : the american motor vehicles industry, 1929-1935 ", Journal of Economic History, 51(2), 317-31.

BRESNAHAN, T., and RAFF, D. (1998), "Plant shutdown behavior during the great depression and the structure of the american motor vehicle industry", Journal of Economic History.

CAlOMiRIs, C., and HuBBARD, R. (1995), «Internal finance and investment : evidence from the undistributed profit tax of 1936-1937 », Journal of Business, 68(4), 443-482.

CARLSON, B. (1995), "The coordination of business organisation and technological innovation within the firm : a case study of the Thomson-Houston Electric Company in the $1880 \mathrm{~s} »$, in LAMOREAUX, N., and RAFF, D., (Eds) (1995), Coordination and information: historical essays on the organisation of enterprise, Chicago : University of Chicago Press.

CHANDler, A. (1977), The visible hand: the managerial revolution in american business, Cambridge, Harvard University Press.

CHANDLER, A. (1992), "Organizational capabilities and the economic history of the industrial enterprise ", Journal of Economic Perspective, 6(3), 79-100.

Chandler, A., Amatori, F., and Hikino, T. (eds) (1997), Big Business and the Wealth of Nations, Cambridge: Cambridge University Press.

Chandler, A., and CoRTADA, J. (eds) (2000), A Nation Transformed by Information: How Information has shaped the US from Colonial Times to Present, Oxford: Oxford University Press.

Chandler, A., Hagstrom, P., and Orjan, S. (eds) (1998), The Dynamic Firm: The Role of Technology, Strategy, Organization and Regions, Oxford: Oxford University Press.

DAVIS, C. (1996), "You are the company: the demands of employment in the emerging corporate culture, Los Angeles, 1900-1930 », Business History Review, 70.

DE LONG, B. (1991), « Did J.P. Morgan's men add value ? An economist's perspective on financial capitalism », in TEMIN, P., (ed.) (1991), Inside the business entreprise : the use and transformation of information, Chicago : University of Chicago Press.

FISHER, F. (1991), "Organizing industrial organization: reflections on the handbook of industrial organization", Brooking Papers on Economic Activity: Microeconomics, 201-225.

GORT, M., and KLEPPER, S. (1982), "Time path in the diffusion of product innovations", Economic Journal, 92, 630-53.

GRIEVES, K. (1989), Sir Eric Geddes, Manchester.

Grossman, S., and HART, O. (1986), « The costs and benefits of ownership : a theory of vertical and lateral integration », Journal of Political Economy, 94, 691-719.

HANNAH, L. (1983), The rise of corporate economy, $2^{\text {nd }}$ ed., Methuen.

HART, O. (1995), Firms, contracts and financial structure, New York: Oxford University Press.

HAYEK, F. (1937), "Economics and Knowledge", Economica, 4.

HOLMSTROM, B., AND KAPLAN, S. (2001), " Corporate governance and merger activity in the United States: Making sense of the 1980's and 1990's », Journal of Economic Perspective, 15(2), 121-44.

HYDE, F. (1962), " Economic theory and business history, Business History, 5(1).

JENKINSON, T., and MAYER, C. (1992), " The assessment: corporate governance and corporate control », Oxford Review of Economic Policy, (3). 
JOHNSON, T. (1991), « Managing by remote control : recent management accounting practice in historical perspective », in TEMIN, P., (ed.) (1991), Inside the business entreprise: the use and transformation of information, Chicago: University of Chicago Press.

JONES, S. (1997), « Transaction costs and the tehory of the firm : the scope and limitations of the new institutional approach », in CASSON, M., and Rose, M., (eds) (1997), Business History, Special Issue : Institutions and the evolution of modern business, 39(4).

KALDOR, N. (1985), Economics without Equilibrium, Cardiff: Cardiff University Press.

KLEPPER, S. (1997), "Industry life cycle", Industrial and Corporate Change, 6(1), 145-181.

KLEPPER, S. [2002a], "Firm survival and the evolution of oligopoly", Rand Journal of Economics, 33(1), 37-61.

KLEPPER, S. [2002b], "The capabilities of new firms and the evolution of the US automobile industry", Industrial and Corporate Change, 11(4), 645-666.

KLEPPER, S., and SimONS, K. (1997), "Technological extinctions of industrial firms : an inquiry into their nature and causes ", Industial and Corporate Change, 6(2), 379-460.

KLEPPER, S., and SIMONS, K. [2000], "The making of an oligopoly : firm survival and technical change in the evolution of the U.S Tire industry", Journal of Political Economy, volume 108(4), 728-760.

KLEPPER, S., et MilleR, J. (1995), “Entry, exit and shakeouts in the United States in new manufactured products ", International Journal of Industrial Organization, 13, 567-91.

KOCKA, J. (1971), "Family and bureaucracy in german industrial management », Business History Review, 45.

KORCZINSKI, M. (1999), «Restrictive practices of capital: employer commercial opportunism, labour militancy and economic performance in the engineering construction industry, 1960-1980 », Business History, 41(3).

LAMOREAUX, N. (1991), "Information problems and banks' specialisation in short-term commercial lending: New England in the $19^{\text {th }}$ century », in TEMIN, P., (ed.) (1991), Inside the business entreprise : the use and transformation of information, Chicago : University of Chicago Press.

LAMOREAUX, N. (1998), " Partnerships, corporations, and the theory of the firm ", American Economic Review, 88(2), 66-71.

LAMOREAUX, N. (2001), "Market trade in patents and the rise of a class of specialized inventors in the $19^{\text {th }}$ century United States, American Economic Review, 91(2), 39-44.

LAMOREAUX, N., and RAFF, D., (Eds) (1995), Coordination and information: historical essays on the organisation of enterprise, Chicago : University of Chicago Press.

LAMOREAUX, N., RAFF, D., and TEMIN, P., (Eds) (1998), Learning by doing in firms, markets and nations, Chicago : University of Chicago Press.

LANGloIs, R., and Foss, N. (1999), «Capabilities and governance: the rebirth of production in the theory of economic organisation" », Kyklos, 52(2).

LANGlois, R., and RoBERTSON, P. (1995), Firms, markets and economic change : a dynamic theory of business institutions, Routledge.

LAZONICK, W. (1991), Business organization and the myth of the economy, Cambridge : Cambridge University Press.

LAZONICK, W. (2002), "Innovative enterprise and historical transformation", Enterprise and Society, 3(1), 3-47.

LAZONICK, W. (2003), “The Theory of the Market Economy and the Social Foundations of Innovative Enterprise", Economic and Industrial Democracy, 24(1), 9-44.

LEE, C. (1990a), "Corporate behaviour in theory and history : I. The evolution of theory, Business History, 32. 
LEE, C. (1990b), "Corporate behaviour in theory and history : II. The historian perspective", Business History, 32.

LOASBY, B. (1991), Equilibrium and Evolution: an Exploration of Connecting Principles in Economics, Manchester: Manchester University Press.

MenARD, C. (2000), Institutions, Contracts and Organizations: Perspectives from New Institutional Economics, Aldershot: Edward Elgar.

MORIKAWA, H. (1975), « Management structure and control devices for diversified zaibatsu business », in Nekagawa, K . (ed.), The strategy and structure of big business, Tokyo.

RAFF, D. (1995), «The puzzling profusion of compensation systems in the interwar automobile industry », in LAMOREAUX, N., and RAFF, D., (eds) (1995), Coordination and information: historical essays on the organisation of enterprise, Chicago: University of Chicago Press.

RAFF, D. (1998), "Representative firm analysis and the character of competition : glimpses from the great depression ", American Economic Review, 88(2), 57-61.

RAFF, D., and TEMIN, P. (1991), « Business history and recent economic theory : imperfect information, incentives, and internal organisation of firms », in TEMIN, P., (ed.) (1991), Inside the business entreprise : the use and transformation of information, Chicago: University of Chicago Press.

READER, W. (1975), Imperial chemical industry : a history, Oxford.

RICHARDSON, G. (1960), Information and Investment, 1990, 2nd edition, Clarendon Press, Oxford.

RICHARDSON, G. (1972), "The Organisation of Industry", Economic Journal, 82.

SHELANSKI, H. and KLEIN, S. (1995), " Empirical research in transaction costs economics : a survey and assessment », Journal of Law, Economics and Organisation, 11, 335-361.

SHLEIFER, A., and VISHNY, R. (1997), « A survey of corporate governance », Journal of Finance, 52, 737-83.

SundERLAND, D. (1999), " Objectionable parasites : the Crown Agents and the purchase of Crown colony government stores, 1880-1914», Business History, 41(4).

Supple, B. (1962), " The uses of business history ", Business History, 4(2).

TEECE, D. (1986), « Profiting from technological innovation : implications for integration, collaboration, licensing, and public policy », Research Policy, 15, 285-305.

TEMIN, P., (Ed) (1991), Inside the business entreprise: the use and transformation of information, Chicago : University of Chicago Press.

TIROLE, J. (1988), The Theory of Industrial Organization, Cambridge, Mass.: MIT Press.

TIROLE, J. (2001), « Corporate Governance », Econometrica, 69(1), 1-35.

WigGins, S. (1991), "The economics of the firm and contracts: a selective survey», Journal of Institutional and Theoretical Economics, 149, 603-661.

Williamson, O. (1985), The economic institutions of capitalism, New York : Free Press.

Williamson, O. (1989), "Transaction costs economics», in SchMALENSEE, R., and Willig, T., (eds), Handbook of industrial organisation, North Holland : Amsterdam.

WILSON, J. (1968), Unilever, 1945-1965 : challenge and response in the post-war industrial revolution, Cassell.

Wilson, J. (1997), British business history - 1720-1994, Manchester and New York: Manchester University Press. 